\title{
REHABILITASI TERHADAP PENYALAHGUNAAN NARKOTIKA \\ DI TINJAU DARI SISTEM PEMIDANAAN INDONESIA
}

\author{
Syafruddin \\ Pasca Sarjana Universitas Borneo Tarakan \\ Syaftrk2013@gmail.com
}

\begin{abstract}
This research is motivated by the increasingly widespread use of narcotic in Indonesia, while the illegal use of narcotics can be viewed as a crime that can be imposed criminal sanctions in accordance with the provisions of Law of 35 of 2009. This narcotic law, in the case of punishment to the narcotic user, adheres to double track system, namely repressive sanction and action sanction. Medical rehabilitation is one of the framework of action sanction. On that basis, this research refers to two objectives: Analyzing the existence of rehabilitation for narcotic user in the perspective of the Indonesian punishment system and Analyzing the consequences for rehabilitation in cases of narcotic crime.

This research is a legal research with normative law research type. The analytical approach uses a statutory approach and a conceptual approach. Sources of legal materials used in this study are primary and secondary legal materials. Primary sources of law relate to written legal products and secular sources of law covering other relevant literature.

The results of research show that the existence of rehabilitation for narcotic user in the perspective of the Indonesian punishment system, is basically one of the forms of sanction which must be undertaken by the user of narcotic who is not the category of dealer, because the philosophy of Law of 35 on 2009 on Narcotic adheres to double track system in the case of sanction for the narcotic user, namely a repressive witness and action sanction, so it can be argued that rehabilitation is a manifestation of the sanction of such action. Furthermore, the determination of rehabilitation for narcotic user based on a judge's ruling may have consequences for drug user to undergo medical rehabilitation as a duty.

.Furthermore, the role of government is very important through the National Narcotics Agency (BNN) to streamline community participation in the framework of medical rehabilitation and social rehabilitation procedures that are very urgent for the recovery of health and mental recovery of those who have become victims of narcotics.
\end{abstract}

Keywords : Rehabilitation, Criminal Sanction, and Narcotic User 


\section{Pendahuluan}

Penyalahgunaan narkotika merupakan suatu tindak kejahatan dan pelanggaran yang mengancam keselamatan, baik fisik maupun jiwa si pemakai dan juga terhadap masyarakat di sekitar secara sosial, maka dengan melalui pendekatan teoritis diatas, bahaya dan akibat dari penyalahgunaan narkotika tersebut dapat bersifat pribadi bagi si pemakai dan dapat pula berupa bahaya sosial terhadap masyarakat atau lingkungan.

Dalam undang-undang nomor 35 Tahun 2009 Tentang Narkotika konsep Rehabilitasi. Hal tersebut tentu saja membingungkan karena rehabilitasi dapat dijatuhkan kepada pecandu narkotika yang tidak diatur dan bukan termasuk dalam Pemidanaan yang ada dalam Pasal 10 KUHP, dalam Pasal tersebut menyebutkan hukuman pidana ada 2 (dua) yaitu pidana pokok dan pidana tambahan. Pidana pokok terdiri dari Pidana Mati, Pidana Penjara Seumur Hidup, Pidana Penjara, Pidana Kurungan dan Pidana denda. Sementara itu pidana tambahan terdiri dari pencabutan hakhak tertentu, perampasan barang-barang tertentu, pengumuman putusan hakim. Sedangkan pidana rehabilitasi tidak termasuk pidana pokok maupun pidana tambahan, oleh karena rehabilitasi medis tidak termasuk ke dalam jenis pemidanaan sebagaimana Pasal 10 KUHP. Namun Undang-undang nomor 35 Tahun 2009 Tentang Narkotika menganut sistem dua jalur (double track system), sehingga stelsel sanksinya mengatur dua hal sekaligus, yaitu sanksi pidana dan sanksi tindakan berupa Rehabilitasi Medis dan Sosial.

Sehubungan dengan itu, penelitian ini bermaksud melakukan analisis seputar rehabilitasi medis bagi pengguna narkotika yang tidak terkategori sebagai pengedar dengan mengkaitkannya sebagai bentuk pemidanaan bagi pengguna natkotika itu sendiri. Untuk menjawab 
kontroversi apakah rehabilitasi tersebut dapat dikategorikan sebagai bentuk pemidanaan bagi pengguna narkotika itu sendiri.

\section{Rumusan Masalah}

Beranjak dari latar belakang masalah, maka dapat dirumuskan masalah sebagai berikut :

a. Keberadaan rehabilitasi bagi pengguna narkotika dalam perspektif sistem pemidanaan Indonesia.

b. Konsekuensi terhadap rehabilitasi pada kasus tindak pidana narkotika

\section{Tinajauan Pustaka}

Penyalahgunaan narkotika sampai saat ini, tidak hanya di pandang sebagai bentuk kejahatan yang sifatnya nasionalitas yakni berada pada batas-batas wilayah negara tetapi juga telah dipandang sebagai kejahatan bersifat transnasional, bentuk kejahatan yang membahayakan seluruh umat manusia. Masalah penyalahgunaan narkotika ini akhirnya mendapat perhatian dunia Internasional. Ancaman atau bahaya yang ditimbulkan oleh tindak pidana narkotika yang merupakan kejahatan transnasioal terorganisasi telah mendapat perhatian dunia, diantaranya adalah The Eight United Nations Congress on the Prevention of Crime and Treatment of Offenders yang diselenggarakan di Havana pada tahun 1990 yang menyatakan bahwa kejahatan narkotika yang terjadi merupakan kejahatan yang serius yang dihadapi oleh umat manusia, oleh karena itu memerlukan kerjasama internasional. Sehubungan dengan itu, kejahatan narkotika yang merupakan kejahatan yang sangat serius dan dapat menghancurkan generasi suatu bangsa maka Pemerintah Indonesia sangat menyadari pentingnya untuk mencegah bahaya yang diakibatkan oleh kejahatan narkotika itu sendiri.

pengedar narkotika dalam terminology yuridis dikategorikan sebagai pelaku (daders) akan tetapi pengguna dapat dikategorikan baik 
sebagai pelaku dan/atau korban. Dalam Undang-Undang Nomor 35 Tahun 2009 tentang Narkotika, pelaku penyalahguna narkotika terbagi atas dua kategori yaitu pelaku sebagai "pengedar" dan/atau "pemakai". Pada UndangUndang narkotika secara eksplisit tidak dijelaskan pengertian pengedar narkotika. "Pengedar Narkotika", secara implisit dan sempit, adalah orang yang melakukan kegiatan penyaluran dan penyerahan narkotika. Menurut ketentuan Undang-undang Nomor 35 Tahun 2009 tentang Narkotika maka "pengedar" diatur dalam pasal 111, 112, 113, 114, 115, 116, 117, 118, 119, $120,121,122,123,124,125$.

Begitu juga terhadap pengguna narkotika. Hakikatnya pengguna adalah orang yang menggunakan zat atau obat yang berasal dari tanaman baik sintesis maupun semi sintesis yang dapat menyebabkan penurunan atau perubahan kesadaran, hilangnya rasa nyeri dan dapat menimbulkan ketergantungan, yang dibedakan dalam golongan-golongan sebagaimana terlampir dalam Undang undang Narkotika. Dalam ketentuan UndangUndang Nomor 35 Tahun 2009 tentang Narkotika maka pengguna diatur dalam pasal 116, 121, 126, 127, 128, 134.

Dalam implementasinya Mahkamah Agung mengeluarkan terobosan dengan mengeluarkan Surat Edaran (SEMA) Nomor 04 Tahun 2010 yang menjadi pegangan pertimbangan hakim dalam memutus kasus penyalahgunaan narkotika.

Pada prinsipnya pengaturan sanksi pidana terhadap pengguna narkoba bagi diri sendiri diatur dalam Pasal 127 Undang-Undang Nomor 35 Tahun 2009 tentang Narkotika, yakni Menggunakan narkoba bagi diri sendiri mengandung maksud bahwa penggunaan tersebut dilakukan tanpa melalui pengawasan dokter. Penggunaan narkoba tanpa melalui pengawasan dokter itulah yang merupakan suatu perbuatan "tanpa hak dan melawan hukum".

Atas dasar itulah, pengguna atau pecandu narkoba dapat dipidanakan. Meskipun demikian, UU Narkotika juga mengatur tentang rehabilitasi bagi pengguna atau pecandu, yakni terdapat dalam Pasal 54, Pasal 55, Pasal 56, Pasal 57, Pasal 58 dan Pasal 103. Di dalam Pasal 103 UU Narkotika, menyebutkan hakim yang memeriksa perkara pecandu narkoba 
dapat melakukan dua hal. Pertama, hakim dapat memutuskan untuk memerintahkan yang bersangkutan menjalani pengobatan dan/atau perawatan apabila pecandu narkoba tersebut terbukti bersalah melakukan tindak pidana narkoba. Kedua, hakim dapat menetapkan untuk memerintahkan yang bersangkutan menjalani pengobatan dan/atau perawatan, apabila pecandu narkoba tersebut tidak terbukti bersalah melakukan tindak pidana narkoba.

Filosofi rehabilitasi medis bagi pecandu narkotika itu sendiri menurut hasil penelitian Achmad Zulfikar Muzakkir15 adalah bertujuan untuk memulihkan kondisi psikologis serta kondisi fisik bagi pecandu agar dapat berinteraksi secara normal, yang dapat diperincikan sebagai berikut:

1) Memulihkan kembali rasa harga diri, percaya diri, kesadaran serta tanggung jawab terhadap masa depan diri, keluarga maupun masyarakat atau lingkungan sosialnya;

2) Memulihkan kembali kemampuan untuk dapat melaksanakan fungsi sosialnya secara wajar.

3) Selain penyembuhan secara fisik juga penyembuhan keadaan sosial secara menyeluruh.

Jadi dapat disimpulkan bahwa sasaran rehabilitasi medis bagi pecandu narkotika yang sudah akut, yang dapat diperincikan adalah sebagai berikut:

1) Meningkatkan insight individu terhadap problem yang dihadapi, kesulitan dan tingkah lakunya.

2) Membentuk sosok self identity yang lebih baik pada individu.

3) Memecahkan konflik yang menghambat dan mengganggu.

4) Merubah dan memperbaiki pola kebiasaan dan pola reaksi tingkah laku yang tidak diinginkan.

5) Meningkatkan kemampuan melakukan relasi interpersonal maupun kemampuan lainnya.

6) Modifikasi asumsi-asumsi individu yang tidak tepat tentang dirinya sendiri dan dunia lingkungannya.

15 Achmad Zulfikar Muzakkir, "Efektivitas Program Rehabilitasi Medis dan Sosial Korban Penyalahgunaan Narkotika dan Obat-Obat Terlaarang Dalam Perspektif Sosiologi Hukum", Skripsi, Fakultas Hukum Universitas Hasanuddin, Makassar, 2016, 43-44. 
7) Membuka jalan bagi eksistensi individu yang lebih berarti dan bermakna atau berguna.

\section{Pembahasan}

\section{A. Rehabilitasi Bagi Pengguna Narkotika Dalam Sistem Pemidanaan Indonesia}

Dalam teori pemidanaan klasik, sebagaimana yang telah peneliti paparkan pada uraian sebelumnya, bahwa penjatuhan sanksi pidana pada hakikatnya merupakan bentuk pembalasan kepada seseorang yang terbukti melakukan kejahatan. Teori pemidanaan klasik, kebanyakan dianut oleh para filosof barat sejak awal abad ke 18 masehi, yang dikenal dengan teori pembalasan atau teori absolut. Salah satu pendapat yang dikemukakan Hegel bahwa hukuman pidana apabila dikaitkan dengan teori absolut, maka sanksi pidana secara mendasar dapat dipandang sebagai bentuk imbalan hukuman yang merupakan dialectische vergelding, sehingga hal tersebut memperlihatkan bahwa pembalasan (vergelding) yang merupakan implikasi yang tak terpisahkan dari akibat yang harus diterima oleh pelaku kejahatan ${ }^{16}$.

Seiring dengan perkembangan jaman, beberapa filosof barat serta ahli hukum pidana barat lainnya, mengkritisi teori absolut yang berkenaan dengan sanksi pidana sebagai bentuk pembalasan bagi pelaku kejahatan atau tindak pidana ${ }^{17}$. Lahirnya teori ini menurut hasil pelacakan literatur peneliti merupakan suatu bentuk negasi terhadap teori absolut (walaupun secara historis teori ini bukanlah suatu bentuk penyempurnaan dari teori absolut), yang hanya menekankan pada

${ }^{16}$ Leden Marpaung, Asas-Asas Teori Praktik Hukum Pidana, Sinar Grafika, Jakarta, 2006, h. 25.

${ }^{17}$ Ohoitimur, Yong, Teori Etika Tentang Hukuman Legal, Gramedia Pustaka Utama, Jakarta, 1997. 
pembalasan dalam penjatuhan hukuman terhadap penjahat. Feurbach sebagai salah satu filsuf penganut aliran ini berpendapat pencegahan tidak usah dilakukan dengan siksaan tetapi cukup dengan memberikan peraturan yang sedemikian rupa sehingga bila orang setelah membaca itu akan membatalkan niat jahatnya. Selain dengan pemberian ancaman hukuman, prevensi umum (general preventie) juga dilakukan dengan cara penjatuhan hukuman dan pelaksanaan hukuman (eksekusi). Eksekusi yang dimaksud dilangsungkan dengan cara-cara yang kejam agar khalayak umum takut dan tidak melakukan hal yang serupa yang dilakukan oleh si penjahat.

Kedua teori ini, secara mendasar, memiliki pandangan yang berbeda tentang tujuan pemidanaan. Menurut teori absolut bahwa tujuan pemidanaan adalah semata-mata bertujuan memberikan rasa jera sehingga patut bagi pelaku kejahatan diberikan sanksi sebagai bentuk pembalasan, sedangkan menurut teori nisbi bahwa penjatuhan pidana janganlah dipandang sebagai bentuk pembalasan semata-mata tetapi nilai filosofis penjatuhan pidana adalah dalam kerangka prevensi atau pencegahan, sehingga penjatuhan pidana haruslah dipandang dalam perspektif pembinaan bagi pelaku kejahatan sehingga tidak melakukan kejahatan untuk kesekian kalinya.

Dari perdebatan kedua teori ini tentang tujuan pemidanaan maka lahirlah teori untuk menengahi kedua teori tersebut, yakni teori gabungan (verenigingstheorien). Teori gabungan merupakan suatu bentuk kombinasi dari teori absolut dan teori relatif yang menggabungkan sudut pembalasan dan pertahanan tertib hukum masyarakat. Dalam teori ini, unsur pembalasan maupun pertahanan tertib hukum masyarakat tidaklah dapat diabaikan antara satu dengan yang lainnya. Artinya, teori gabungan yang menitikberatkan unsur pembalasan dan juga menitikberatkan pertahanan tertib masyarakat. 
Teori gabungan ini memposisikan secara seimbang antara pembalasan dan pertahanan tertib masyarakat ${ }^{18}$.

Hakikat sanksi pidana, bagaimanapun juga merupakan ultimum remedium ${ }^{19}$ yakni sebagai senjata terakhir untuk menciptakan tatanan ketertiban di tengah masyarakat serta berfungsi menciptakan rasa aman ditengah-tengah masyarakat.

\section{B. Analisis Rehabilitasi Sebagai Bentuk Pemidanaan Bagi Pengguna Narkotika}

Pada pembahasan ini, peneliti memberikan analisis tentang keberadaan rehabilitasi medis bagi pecandu berat narkotika yang tidak terkategori sebagai pengedar dalam konteks apakah rehabilitasi itu sendiri dapat dipandang sebagai bentuk pemidanaan bagi pecandu narkotika tersebut. Apabila mencermati substansi pasal-pasal dalam Undang-Undang Nomor 35 Tahun 2009 tentang Narkotika, sebagaimana yang diatur dalam pasal 54 dan 55 maka bagi pengguna narkotika yang tidak dikategorikan sebagai pengedar, berkewajiban untuk menjalani masa rehabilitasi. Ketentuan tersebut, diatur dalam pasal 54 bahwa "Pecandu Narkotika dan korban penyalahgunaan Narkotika wajib menjalani rehabilitasi medis dan rehabilitasi sosial", dan selanjutnya pasal 55 .

Apabila mencermati ketentuan pasal 103 maka menurut peneliti dapat ditafsirkan secara gramatikal bahwa kalimat pada ayat (2) yakni “...diperhitungkan sebagai masa menjalani hukuman” maka ini merujuk pada ketentuan bahwa rehabilitasi masuk dalam kategori sebagai masa pemidanaan atau sebagai salah satu bentuk sanksi yang harus dijalani oleh pecandu narkotika itu sendiri apalagi rehabilitasi medis telah dinyatakan melalui putusan pengadilan (putusan hakim).

\footnotetext{
${ }^{18}$ Nandang Sambas, Pembaruan Sistem Pemidanaan Anak di Indonesia, Graha Ilmu, Yogyakarta, 2009.

${ }^{19}$ Roeslan Saleh, Pikiran-pikiran Tentang Pertanggungjawaban Pidana, Ghalia Indonesia, Jakarta, 1982.
} 
Apalagi diperkuat dengan keluarnya Surat Edaran Mahkamah Agung (SEMA) Nomor 4 Tahun 2010 tentang Penempatan Penyalahgunaan Narkotika, Korban penyalahgunaan dan pecandu narkotika ke dalam Lembaga Rehabilitasi Medis dan Rehabilitasi Sosial tentang dasar pertimbangan atau acuan hakim dalam menjatuhkan sanksi rehabilitasi.

Double track system yang dapat dimaknakan sebagai karakteristik sanksi bagi pecandu narkotika, yakni rehabilitasi medis merupakan salah satu segi dari sanksi yang sifatnya pemberian tindakan bagi pecandu tersebut agar menjadi pribadi yang lebih baik, pemulihan mental, serta pemulihan kesehatan sebagai dampak buruk dari narkotika. Menurut C. Ray Jeffery ${ }^{20}$ bahwa treatment merupakan salah satu model sanksi untuk memberi tindakan perawatan (treatment) dan perbaikan (rehabilitation) kepada pelaku kejahatan sebagai pengganti dari penghukuman. Argumen aliran positif ini dilandaskan pada alasan bahwa pelaku kejahatan adalah orang yang sakit sehingga membutuhkan tindakan (treatment) dan perbaikan (rehabilitation).

Kalau mengacu kepada pandangan tentang perawatan sebagai salah satu bentuk sanksi bagi pengguna narkotika maka rehabilitasi medis dapat dipandang sebagai salah satu bentuk sanksi, sebagaimana yang juga dipertegas oleh Ayat (2) Pasal 103 Undang-Undang Nomor 35 Tahun 2009 tentang Narkotika.

Sehubungan dengan hal tersebut, hasil penelitian dari Hafied Ali Gani21, berpandangan bahwa setiap pecandu narkotika itu adalah orang yang sakit fisiknya dan sakit jiwanya, oleh karena kecanduannya pada narkotika. Dia pasti mencari pemenuhan kebutuhan narkotika dengan cara apapun, sehingga bagi penyalahguna narkotika perlu

\footnotetext{
${ }^{20}$ Diah Gustiniati dan Dona Raisa Monica, Pemidanaan dan Sistem Pemasyarakatan Baru, CV Anugrah Utama Raharja, Bandar Lampung, 2016, h. 24.

21 Hafied Ali Gani, Loc. Cit.
} 
direhabilitasi dan diobati ketimbang dia harus ditempatkan di dalam Lembaga Pemasyarakatan (LAPAS), sebab dikhawatirkan dia akan terus melakukan tindakan-tindakan kejahatan yang baru lainnya di dalam lembaga pemasyarakatan, seperti praktek suap menyuap dengan oknum, melakukan kekerasan dan menjadi pembunuh, bahkan menjadi bagian dari sindikat bandar narkotika di dalam lembaga pemasyarakatan yang sering banyak terjadi baru-baru ini. Untuk itu bagi mereka yang menjadi penyalahguna narkotika ini, paling tidak disalurkan ke Pusat Lembaga Rehabilitasi untuk diobati.

Tujuan utama dari rehabilitasi sebagai upaya depenalisasi adalah agar pecandu narkotika yang telah ketergantungan terhadap narkotika setelah keluar dari lembaga rehabilitasi dapat pulih lagi dan angka kambuh dapat turun, karena berdasarkan survey yang ada bila menggunakan konsep sanksi pidana pada pecandu narkotika, maka mayoritas pecandu setelah keluar dari Lembaga Pemasyarakatan mereka berpeluang melakukan penyalahgunaan narkotika kembali. Alasannya karena di dalam Lembaga Pemasyarakatan tidak dilakukan metode penanganan pecandu narkotika secara optimal seperti di Lembaga Rehabilitasi sebagai contoh tidak dilakukannya detoksifikasi.

Menurut peneliti rehabilitasi medis, secara normatif tetap dipandang sebagai sebuah bentuk sanksi pidana dengan penekanan mengacu kepada Ayat (2) Pasal 103 Undang-Undang Nomor 35 Tahun 2009 tentang Narkotika dengan kata-kata...."Masa menjalani pengobatan dan/atau perawatan bagi Pecandu Narkotika sebagaimana dimaksud pada ayat (1) huruf a diperhitungkan sebagai masa menjalani hukuman. Maknanya adalah menurut peneliti, pembuat undang-undang telah menempatkan rehabilitasi medis sebagai salah satu bentuk sanksi pidana bagi pecandu narkotika yang perlakuan sanksinya tidak dalam bentuk hukuman penjara atau denda. Hanya saja menurut peneliti, Undang-Undang Nomor 35 Tahun 2009, tidak 
memberikan penegasan secara spesifk dan tegas tentang kedudukan rehabilitasi medis sebagai bentuk sanksi bagi pecandu narkotika tetapi hanya menyebutkan secara tersirat bahwa rehabilitasi medis merupakan salah satu bentuk penghukuman bagi pecandu narkotika sebagaimana yang disebutkan dalam Ayat (2) Pasal 103 UndangUndang Nomor 35 Tahun 2009 tentang Narkotika.

Sanksi pidana penjara pada dasarnya untuk memberikan efek jera bagi pecandu atau pengguna narkotika yang masih mengulangi perbuatannya, padahal telah menjalani masa rehabilitasi medis. Artinya, dengan mengutip pendapat Utrecht bahwa apabila ditinjau dari teori-teori pemidanaan maka sanksi tindakan dalam bentuk perawatan medis tersebut merupakan sanksi yang tidak membalas. Ia hanya semata-mata ditunjukkan pada prevensi khusus yakni melindungi masyarakat dari ancaman yang dapat merugikan kepentingan masyarakat, sedangkan sanksi pidana penjara pada satu sisi merupakan ultimum remedium yakni untuk memberikan efek jera. Singkatnya, sanksi pidana berorientasi pada ide pengenaan sanksi terhadap pelaku suatu perbuatan, sementara sanksi tindakan berorientasi pada ide perlindungan masyarakat.

\section{KONSEKUENSI REHABILITASI BAGI PENGGUNA NARKOTIKA PADA KASUS TINDAK PIDANA NARKOTIKA}

Rehabilitasi dalam Perspektif Penalisasi Bagi Pengguna Narkotika Secara Tidak Sah. Peneliti membangun argumentasi ini dengan bersandarkan kepada dalil normatif dengan merujuk kepada Pasal 127 Undang-Undang Nomor 35 Tahun 2009. Ketentuan pasal tersebut, terutama ditegaskan dalam Ayat (3), menunjukkan bahwa rehabilitasi medis termasuk juga rehabilitasi sosial masuk kategori salah satu bentuk sanksi pidana bagi pecandu berat narkotika. Merujuk ketentuan Ayat (3) Pasal 127 tersebut lalu dikuatkan dengan ketentuan Pasal 103 Undang-Undang Nomor 35 Tahun 2009 tentang Narkotika dengan kata-kata...."Masa menjalani pengobatan dan/atau 
perawatan bagi Pecandu Narkotika sebagaimana dimaksud pada ayat (1) huruf a diperhitungkan sebagai masa menjalani hukuman, maka tentu saja rehabilitasi medis termasuk juiga rehabilitasi sosial, semestinya dipandang sebagai sanksi pidana yang berkarakteristik penal.

Peneliti membangun argumentasi untuk menetapkan rehabilitasi sebagai bagian dari sanksi pidana yang harus dibebankan kepada pecandu narkotika adalah berdasarkan kepada logika sistem pemidanaan perspektif double track system. Artinya, Memperhatikan rumusan sanksi dalam Undang-Undang Narkotika tersebut, maka dapat dikatakan bahwa perumusan sanksi terhadap tindak pidana penyalahgunaan narkotika mengacu pada double track system, karena berdasarkan tinjauan victimologi bahwa pecandu narkotika adalah sebagai self victimizing victims yaitu korban sebagai pelaku, victimologi tetap menetapkan penyalahgunaan narkotika sebagai korban, meskipun korban dari tindak pidana/kejahatan yang dilakukannya sendiri, sehingga bagi pecandu narkotika yang juga sebagai korban patut untuk mendapat perlindungan.

\section{Urgensi Rehabilitasi Dalam Perspektif Pencegahan Penyalahgunaan} Narkotika.

Rehabilitasi merupakan fasilitas yang sifatnya semi tertutup, maksudnya hanya orang-orang tertentu dengan kepentingan khusus yang dapat memasuki area ini. Rehabilitasi narkotika adalah tempat yang memberikan pelatihan keterampilan dan pengetahuan untuk menghindarkan diri dari narkotika. Rehabilitasi juga sebagai rangkaian proses hukum atau perlindungan yang setara dengan mengecualikan sebagai pengganti penahanan hukuman penjara, pecandu dengan dua atau lebih keputusan kriminal sebelumnya ${ }^{22}$. Sesuai dengan ketentuan Pasal 54 Undang-undang Narkotika tersebut, maka mereka yang wajib menjalani rehabilitasi adalah pecandu narkotika dan korban penyalahguna narkotika. Pecandu narkotika menurut Pasal 1 angka 13 adalah" orang yang menggunakan atau menyalahgunakan narkotika, baik secara fisik maupun psikis". Sedangkan

${ }^{22}$ Soeparman, Ilmu Penyakit Dalam Jilid 2, FKUI, Jakarta, 2000,h.37 
yang dimaksud korban penyalahguna narkotika adalah orang yang tidak mengetahui bahwa narkotika yang digunakannya tersebut tanpa hak atau melawan hukum. Tujuan penjatuhan tindakan rehabilitasi tidak terlepas dari tujuan pemidanaan pada umumnya yang berdasarkan pada teori pemidanaan yaitu teori relatif atau teori tujuan, yaitu pidana rehabilitasi merupakan suatu penjatuhan tindakan yang dimaksudkan agar dapat memperbaiki orang yang melakukan tindak pidana, karena tujuan dari penjatuhan tindakan rehabilitasi adalah untuk memberikan jaminan penanganan paripurna kepada korban penyalahgunaan narkotika melalui aspek hukum, aspek medis, aspek sosial, aspek spiritual, serta pengembangan pendidikan dan pelatihan dalam bidang narkotika secara terpadu.

Berdasarkan penjelasan tersebut, maka menurut peneliti rehabilitasi dipandang sangat urgen dalam rangka pemulihan mental para pecandu narkotika yang disisi lain juga berguna bagi pemulihan kesehatan fisik pecandu narkotika tersebut. Dari normatif, rehabilitasi akan dipandang sangat urgen dalam kerangka kemanfaatan hukum. Kemanfaatan hukum itu, adalah membangun kesadaran hukum para pengguna narkotika untuk membangun persepsi bahwa penyalahgunaan narkotika tidak hanya berbahaya bagi diri, keluarga, dan lingkungan masyarakatnya, tetapi juga untuk membangun persepsi hukum bahwa penyalahgunaan narkotika pada hakikatnya merupakan sebuah pelanggaran hukum yang pelakunya dapat saja mendapat ancaman hukuman pidana yang sangat berat sampai kepada hukuman mati sekalipun.

\section{Kesimpulan}

Peneliti memberikan beberapa pokok rumusan kesimpulan dengan mengacu kepada beberapa pokok rumusan masalah sebagai berikut:

1. Keberadaan rehabilitasi bagi pengguna narkotika dalam perspektif sistem pemidanaan Indonesia, pada dasarnya merupakan salah satu bentuk sanksi yang harus dijalani oleh para pengguna narkotika yang 
bukan kategori pengedar, karena falsafah Undang-Undang Nomor 35

Tahun 2009 tentang Narkotika menganut double track system dalam hal sanksi bagi pengguna narkotika tersebut, yakni sanksi represif dan sanksi tindakan, sehingga dapat dikemukakan bahwa rehabilitasi merupakan wujud dari sanksi tindakan tersebut.

2. Berdasarkan putusan hakim di pengadilan yang sudah mempunyai kekuatan Hukum tetap (inkracht) maka bagi pengguna narkotika yang telah ditetapkan berdasarkan putusan hakim harus menjalani rehabilitasi sehingga sebagai konsekuensinya atau menjadi akibat hukum bagi dia adalah wajib menjalani rehabilitasi.

\section{DAFTAR PUSTAKA}

\section{Buku Teks}

Ali, Mahrus, Dasar-dasar Hukum Pidana, Sinar Grafika, Jakarta, 2011.

Gustiniati, Diah dan Monica, Dona Raisa, Pemidanaan dan Sistem Pemasyarakatan Baru, CV Anugrah Utama Raharja, Bandar Lampung, 2016.

Hamzah, Andi, Asas-Asas Hukum Pidana, Sinar Grafika, Jakarta, 2008.

Ibrahim, Johny, Teori dan Metodologi Penelitian Hukum Normatif, Bayu Media Publishing, Malang, 2006.

Kartanegara, Satochid, Hukum Pidana Bagian Satu, Balai Lektur Mahasiswa, Jakarta, 2008.

Krisnawaty, Dani dan Eddy O.S Hiariej, Bunga Rampai Hukum Pidana Khusus, Pena Pundi Aksara, Jakarta 2006.

Lamintang, P.A.F.,Dasar-dasar Hukum Pidana Indonesia, Sinar Baru, Bandung, 1984. 
Lopa, Baharudin, Etika Pembangunan Hukum Nasional Dalam Identitas Hukum Nasional, Fakultas Hukum UII, Yogyakarta, 1997.

Marpaung, Leden, Asas-Asas Teori Praktik Hukum Pidana, Sinar Grafika, Jakarta, 2006.

Marzuki, Peter Mahmud, Penelitian Hukum, Prenada Media, Jakarta 2003,Edisi Revisi 2005.

Muladi dan Barda Nawawi Arief, Teori -teori dan Kebijakan Pidana, Alumni, Bandung, 1984.

Moeljatno, Asas-asas Hukum Pidana, Rineka Cipta, 2002.

Ohoitimur, Yong, Teori Etika Tentang Hukuman Legal, Gramedia Pustaka Utama, Jakarta, 1997.

Prakoso, Joko, Hukum Penintesir Di Indonesia, Liberty, Jogjakarta, 1988.

Prodjodikoro, Wirjono, Asas-Asas Hukum Pidana Di Indonesia,PT Refika Aditama, Bandung, 2008.

Radie, Muhammad Teuku, Pembangunan Hukum Nasional Dalam Perspektif Kebijakan Dalam Identitas Hukum Nasional, Fakultas Hukum UII, Yogyakarta, 1997.

Rahardjo, Satjipto, Hukum dan Perubahan Sosial, Alumni, Bandung, 1983.

SS, Soehardjo, Politik Hukum dan Perkembangan Masyarakat, Sinar Baru, Bandung, 1983.

Saleh, Roeslan, Pikiran-pikiran Tentang Pertanggungjawaban Pidana, Ghalia Indonesia, Jakarta, 1982.

Saleh, Roeslan, Stelsel Pidana Indonesia, Angkasa Baru, Jakarta, 1983.

Sambas, Nandang, Pembaruan Sistem Pemidanaan Anak di Indonesia, Graha Ilmu, Yogyakarta, 2009.

Soeparman, Ilmu Penyakit Dalam Jilid 2, FKUI, 2000, Jakarta.

Sholehuddin, M, Sistem Sanksi Dalam Hukum Pidana, PT. Raja Grafindo Persada, Jakarta, 2002.

Sudarto, Sistem Sanksi Dalam Hukum Pidana (Ide dasar Double Track System dan Implementasinya), Raja Grafindo Persada, Jakarta, 2002. 
Sugandhi, R, Buku Kitab Undang-undang Hukum Pidana (KUHP), Usaha Nasional, Surabaya, 2010.

Widjaya, A.W., Masalah Kenakalan Remaja dan Penyalahgunaan Narkotika, Tanpa Penerbit dan Tahun.

Wibisono, Koento, Etika Pembangunan Hukum Nasional Dalam Identitas Hukum Nasional, Fakultas Hukum UII, Yogyakarta, 1997.

\section{Jurnal dan Karya Ilmiah}

Gani, Hafid Ali, dkk, "Rehabilitasi Sebagai Upaya Depenalisasi Bagi Pecandu Narkotika", Jurnal Hasil Penelitian, Fakultas Hukum Universitas Brawijaya, Malang, 2015.

Indrawati, Windha, "Pola Rehabilitasi Sosial Wanita Tuna Susila di Unit Pelaksana Teknis Rehabilitasi Sosial Tuna Susila Kota Kediri”, Artikel Pada Jurnal Pendidikan Kewarganegaraan, Fakultas Ilmu sosial Universitas Negeri Malang, Vol. I, No.1, 2014.

LHC, Hulsman, The Dutch Criminal Justice System From a Comparative Legal Perspective, di dalam D.C Fokkema (Ed), Introduction to Dutch Law For Foreign Lawyers (Kluwer Deventer, The Nederlands 1978).

Muzakkir, Achmad Zulfikar, "Efektivitas Program Rehabilitasi Medis dan Sosial Korban Penyalahgunaan Narkotika dan Obat-Obat Terlaarang Dalam Perspektif Sosiologi Hukum", Skripsi, Fakultas Hukum Universitas Hasanuddin, Makassar, 2016.

Sudarto "Suatu Dilema Dalam Pembaharuan Sistem Pidana Indonesia", Pidato Pengukuhan Jabatan Guru Besar Tetap Dalam Hukum Pidana, Universitas Diponegoro, Semarang, 21 Desember, 1974

\section{Laman Internet}

BNN, www.bnn.go.id, 2014 